\title{
A retrospective study of maternal and fetal outcome of viral hepatitis in pregnancy
}

\author{
Chaitra S, Deepika SP, Chandushree, Renuka Ramaiah \\ Correspondence: Dr Chaitra S, Senior resident, ESIC Medical college, Bangalore, Karnataka, \\ India; Email - chaittra.shiv@gmail.com
}

Distributed under Attribution-Non Commercial-Share Alike 4.0 International (CC BY-NC-SA 4.0)

\begin{abstract}
Objectives: This study was conducted to evaluate the cause, course of the condition in pregnancy, maternal and fetal outcome in diagnosed cases of viral hepatitis in pregnancy. Methodology: A retrospective study was conducted and 114 numbers of pregnant women were found to be infected with hepatitis. Women were enrolled in the study after confirmation by performing the viral profile. The hematological and biochemical data were collected from the data base. Results: The prevalence of pregnant women infected with hepatitis in pregnancy was found to be $0.67 \%(114 / 16886)$. It was found that women in the age group of 21 to 30 had the highest prevalence (80) $70.1 \%$. Most of the women were primigravida (65) $57.01 \%$ and detected predominantly in the first trimester. Maternal complications associated with the condition included abruption $4(3.5 \%)$, coagulation dysfunction (8) $7.01 \%$ and encephalopathy (3) $2.6 \%$. Maternal mortality was noted in (2) $1.7 \%$ of the women and was highly significant in women with features of encephalopathy, high bilirubin levels, high liver enzymes and prolonged prothrombin time. Perinatal mortality was noted in $7(6.1 \%)$ and the main cause is attributed to preterm and low birth weight. Conclusions: Hepatitis is a condition, which turns to a very dreaded state as the pregnancy progresses. When associated or superimposed with conditions such as gestation hypertension it makes it even difficult to manage and accelerates the complications due to liver failure.
\end{abstract}

Keywords: Hepatitis B virus, pregnancy, maternal and fetal prognosis, hepatocellular carcinoma.

Hepatitis B virus (HBV) is a worldwide health problem today. WHO estimated in 2009 that more than 2 billion people are infected by HBV infection at one or the other point of their life and 350 million people across the world are chronic carrier of the HBV. The estimated mortality is one million annually. ${ }^{1}$ Viral hepatitis in pregnancy is a debatable condition throughout the world. Udaya Kumar et al and Sookia et al have reported that both fetal and maternal outcome can vary so widely from no complications to the worst morbidity and even mortality ${ }^{2,}{ }^{3}$. The geographical area has a peculiar association with the maternal infection. Studies have found that there is no significant increase in the maternal mortality due to hepatitis E in south India whereas the association is very high in the north India ${ }^{4,5}$.

Different type of hepatitis infection has different concern. Hepatitis A is transmitted by faeco-oral route and does not have influence on the course of pregnancy whereas Hepatitis B, when acquired around pregnancy due to its high viral load has a high rate of vertical

Received: $24^{\text {th }}$ May 2018. Accepted: $31^{\text {st }}$ January 2019.

Chaitra S, Deepika SP, Chandushree, Ramaiah R. A retrospective study of maternal and fetal outcome of viral hepatitis in pregnancy. The New Indian Journal of OBGYN. 2019; 6(1):28-31 
transmission, this can lead to serious consequences in the child as it can translate into liver cirrhosis or hepatocellular carcinoma. Hepatitis $\mathrm{C}$ is popularly known for its vertical transmission leading to hepato-cellular carcinoma in both the mother and the child. Hepatitis E is usually self limiting, benign form in non pregnant status but which turns grievous in pregnancy. Overall the association of viral hepatitis and fulminant hepatic failure is high ${ }^{2,6,7}$. Singh et al has reported the huge concern of vertical transmission of hepatitis $E^{8}$. Various studies have shown a very wide difference in the clinical course and outcome in pregnancy ${ }^{9,10}$. Hence this study is conducted to study the prevalence of hepatitis in pregnancy, the clinical course and maternal fetal outcome.

\section{Methodology}

We conducted a retrospective study over a period of 5 years from January 2013 to December 2017, in ESIC medical college, Bangalore. Total 114 numbers of women were diagnosed with hepatitis infection. HELLP, severe preeclampsia, drug induced hepatitis and acute fatty liver of pregnancy were excluded. Biochemical test reports, liver function test, coagulation profile, and serological tests for IgM anti-HAV, HBs antigen, IgM anti-HEV, and IgM anti-HCV were collected and tabulated. The clinical course, the management options were studied. Maternal complication like premature uterine contractions, placental abruption, and premature rupture of membrane and fetal complications like prematurity, fetal ascites, meconium aspiration, and neonatal jaundice were studied. Data were expressed in tables as number and percentage.

\section{Results}

During the study period, a total of 16,886 women registered and delivered with us, 114 numbers of pregnant women were found to be infected with hepatitis. The

Table 1: Demographic profile

\begin{tabular}{ccc}
\hline Categories & & Number \\
\hline Age in years & $<20$ & 15 \\
& $21-30$ & 65 \\
Gravida & $>30$ & 34 \\
& Primigravida & 65 \\
Antenatal care & Multigravida & 49 \\
& Regular & 104 \\
& Irregular & 10 \\
\hline
\end{tabular}

prevalence of pregnant women infected with hepatitis in pregnancy was found to be $0.67 \% \quad(114 / 16886)$. Table 1 shows the demographic profiling of these women.
Mean bilirubin level ranged between $8.02 \pm 8.12 \mathrm{mg} / \mathrm{dl}$. The biochemical parameters are shown in Table 2.

Table 2: Biochemical parameters

\begin{tabular}{ll}
\hline Biochemical parameters & Mean \pm SD \\
\hline Total bilirubin in $\mathrm{mg} / \mathrm{dl}$ & $8.02 \pm 8.12$ \\
AST in $\mathrm{u} / \mathrm{l}$ & $345 \pm 561.7$ \\
ALT in $\mathrm{u} / \mathrm{l}$ & $343 \pm 432.22$
\end{tabular}

Etiologies were HAV in $3(2.6 \%), \mathrm{HBV}$ in 106 (92.9\%), $\mathrm{HCV}$ in $1(0.8 \%)$, HEV in $4(3.5 \%)$ patients. Intrahepatic cholestasis was diagnosed in $11(0.65 \%)$ patients after performing an abdominal scan (Table 3). Maternal outcome and complications were analyzed in terms of mode of delivery, 43 (37.7\%) patients delivered vaginally, whereas $71(62.2 \%)$ underwent caesarean section and the

Table 3: Viral marker

\begin{tabular}{ccc}
\hline Etiology & Number of patients & Percentage \\
\hline HAV & 3 & 2.6 \\
HBV & 106 & 92.9 \\
HCV & 1 & 0.8 \\
HEV & 4 & 3.5 \\
HAV+HEV & Nil & Nil \\
HBsAg + & Nil & Nil
\end{tabular}

Anti HEV

most common cause being prolonged leak per vagina and fetal distress. Other complications noted were, Table 4: Maternal outcome and complications

\begin{tabular}{lccccc} 
Maternal outcome & HAV & HBV & HCV & HEV \\
\hline Modes of & Vaginal & 3 & 31 & 1 & 3 \\
delivery $\quad$ Instrumental & 0 & 5 & 0 & 0 \\
& Caesarian & 0 & 70 & 0 & 1 \\
Coagulopathy & 0 & 6 & 0 & 2 \\
Fatal hepatitis & 0 & 5 & 0 & 1 \\
Hepatic encephalopathy & 0 & 3 & 0 & 0 \\
Maternal mortality & 0 & 2 & 0 & 0 \\
\hline
\end{tabular}

coagulopathies, encephalopathy and Fulminate hepatic failure (Table 4). Hundred nine (109) women with

Table 5: Fetal outcome

\begin{tabular}{ccccc}
\hline Fetal outcome & HAV & HBV & HCV & HEV \\
\hline $\begin{array}{c}\text { Preterm } \\
\begin{array}{c}\text { Intra uterine fetal } \\
\text { demise }\end{array}\end{array}$ & 0 & 33 & 0 & 1 \\
Neonatal icteric & 2 & 5 & 0 & 0 \\
\hline
\end{tabular}

hepatitis delivered live babies out of which in $2(1.7 \%)$ early neonatal deaths occurred. There were 5 number of intrauterine deaths, $1(0.8 \%)$ still births, 2 (1.7\%) early neonatal deaths, 34 (29.8\%) preterm births, 30 (26.3\%) low birth weight babies, $24(21.05 \%)$ babies required NICU admission (Table 5). 


\section{Discussion}

Viral hepatitis is the commonest cause of jaundice in pregnancy, a wide range of outcomes have been explained raging from asymptomatic to fatal outcome ${ }^{3}$. In pregnancy, most of the cases of hepatitis are unaltered whereas hepatitis E has a very fatal outcome and attributed to the highest cause of maternal mortality in endemic areas ${ }^{11}$.

In the study we conducted most of the cases of the infection were noted between 21 to 30 years of age, attributing to (65) $57.01 \%$, which is the consistent results obtained by Sahai et $\mathrm{al}^{11}$, Krishnamoorthy et $\mathrm{al}^{12}$ and Madan et $\mathrm{al}^{13}$. Most of the women belonged to the lower middle socio economic status and from education point of view (67) $58.7 \%$ were literate's, whereas $70 \%$ were literates in Shukla et al $^{14}$ and upto $73.8 \%$ in a study conducted by Ashoka et al ${ }^{15}$. Primigravida (65) 57.01\% constituted the largest group of women to have been diagnosed with the viral infection and $56(49.1 \%)$ were diagnosed for the first time with no symptoms in pregnancy, which was similar with result obtained by Veronica et al $(48 \%)^{16}$. A study conducted by Elsheikh et al states a different result of the second gravid having the highest prevalence ${ }^{17}$. Hepatitis B infection was responsible for maximum cases of viral infection in our study constituting to (106) $92.9 \%$. Similar results was noted in the study conducted by Shukla et al ${ }^{14}$, whereas the study conducted by Jaiswal et $\mathrm{al}^{18}$ and Aziz et $\mathrm{al}^{19}$ reported the commonest virus to be hepatitis E.

There was no maternal mortality in our study attributing to the lower prevalence of hepatitis E, in various study conducted by Sahai et $\mathrm{al}^{11}$ and Patil et $\mathrm{al}^{20}$ the mortality rate as high as $18 \%$ was reported, where the prevalence of hepatitis $\mathrm{E}$ was much higher. The morbidity in the form of coagulation failure, encephalopathy and fulminant hepatic failure were seen in the third trimester and women with irregular antenatal check up. Most of the studies performed do not provides extensive report on the fetal outcome. Of the 114 women infected with hepatitis, 34 (29.8\%) delivered preterm which was very much lower than the result reported by Patra et al (65\%) and Kumar et al $(70 \%)^{5,7}$. Five $(4.3 \%)$ of the women had intrauterine fetal demise and neonatal jaundice was seen in 42 $(36.8 \%)$ babies. All the babies were provided with immunization and immunoglobulins by the following paediatrician.

\section{Conclusion}

Infected women with viral hepatitis in pregnancy can lead to fetal wastage and increase the maternal morbidity. In our hospital and most of the studies conducted in south report the highest cause being hepatitis B. The need for hospitalization of the women with jaundice must be insisted and treated energetically.

\section{Conflict of interest: None. Disclaimer: Nil.}

\section{References}

1)World Health Organization. Viral hepatitis: Report by the Secretariat. Geneva: WHO. 2009.

2)Udayakumar N, Mohajar MA, Shata MT. Hepatitis E and Pregnancy: Understanding the Pathogenesis. Liver International. 2008;1190-99.

3)Sookian S. Liver disease during pregnancy: acute viral hepatitis. Ann Hepatol. 2006; 5(3): 231-6.

4)Rasheeda CA, Navaneethan U, Jayanthi V. Liver Disease in pregnancy and its influence on maternal and fetal mortality - a prospective study from Chennai, Southern India. Eur J Gastroenterol Hepatol. 2008; 20(4): 362-4.

5)Kumar A, Beniwal M, Kar P, Sharma JB, Murthy NS. Hepatitis E in pregnancy. Int J Gynaecol Obstet. 2004; 85(3): 240-4.

6)Purcell R, Emerson S. Viral hepatitis. In: Mendell GL, Douglas RG, Bennett JE, Dolin R, eds. Menell, Douglas and Bennett's Principles and Practice of infectious Diseases. 6th edn. New York: Elsevier / Churchill Livingstone; 2005. 2204-17

7)Patra S, Kumar A, Trivedi SS, Puri M, Sarin SK. Maternal and fetal outcomes in pregnant women with acute hepatitis $\mathrm{E}$ virus infection. Ann Intern Med. 2007;147(1): 28-33.

8)Singh S, Mohanty A, Joshi YK, Deka D, Mohanty S, Panda SK. Mother to child transmission of hepatitis E virus infection. Indian J Pediatr. 2003; 70(1): 37-9.

9)Beniwal M, Kumar A, Kar P, Jilani N, Sharma JB. Prevalence and severity of acute viral hepatitis and fulminant hepatitis during pregnancy: a prospective study from north India. Indian J med Microbiol. 2003; 21(3): 184-5

10)Jaiswal SPB, Jain AK, Naik G, Soni N, Chitnis DS. Viral Hepatitis during pregnancy. Int J Gynaec Obstet.

2001;72:103-8 
The New Indian Journal of OBGYN. 2019 (July-December); 6(1)

11)Sahai S, Mishra V, Ganga D, Jatav OP. Viral Hepatitis in Pregnancy - A study of its effect on maternal and foetal outcome. Journal of the association of physicians of india. 2015; 63(1): 28-33.

12)Krishnamoorthy J, Murugesan A. Jaundice during pregnancy: maternal and fetal Contraception, Obstetrics and Gynecology. 2016; 5(8): 2541-5.

13)Madan A, Soni S, Dogra UA, Neki NS. Prevalence of viral hepatitis in pregnancy: An observational study. International journal of research in medical sciences. 2017 3(6): 98-104.

14)Shukla S, Mehta G, Jais M, Singh A. A Prospective Study on Acute Viral Hepatitis in Pregnancy;

Seroprevalence, and Fetomaternal Outcome of 100 cases. Journal of Bioscience and Technology. 2011; 2 (3): 279-86.

15)Kumar A, K. Sharma A, Gupta RK, Kar P, Chakravarti A. Prevalence \& risk factors for hepatitis $\mathrm{C}$ virus among pregnant Women. Indian J Med Res. 2007; 126(3): 211-5.

16)Veronica Irene Y, Kaur V. HEV infection in pregnancy. J Obstet Gynecol India. Mar/Apr 2006; 56(2):146-8.

17)Elsheikh RM, Daak AA, Elsheikh MA, Karsany MS. Adam Hepatitis B virus and hepatitis $C$ virus in pregnant Sudanese women. Virol J. 2007; 4: 104.
18)Aziz AB, Hamid S, Iqbal S, Islam W, Karim SA. Prevalence and severity of viral hepatitis in Pakistani pregnant women: a five year hospital based study. J Pak Med Assoc. 1997; 47(8): 198-201.

19)Vincent JL, Moreno R, Takala J, Willatts S, De Mendonça A, Bruining H, et al. The SOFA (Sepsis Related Organ Failure Assessment) score to describe organ dysfunction/failure. On behalf of the Working Group on SIRS - Related Problems of the European Society of Intensive Care Medicine. Intensive Care Med. 1996; 22(7): 707-10.

20)Patil M, Jain P, Patankar A. A prospective study of maternal and fetal outcome of viral hepatitis in pregnancy. Int J Adv Res. 2017; 5(9): 70-5.

\section{Chaitra $S^{1}$, Deepika $S^{2}$, Chandushree ${ }^{3}$, Renuka Ramaiah $^{4}$ \\ ${ }^{1}$ Senior Resident; ${ }^{2}$ Junior Resident; ${ }^{3}$ Senior Resident; \\ ${ }^{4}$ Professor and Head of the Department, Department of Obstetrics and Gynaecology, ESIC Medical college, Bangalore, Karnataka, India.}

